\title{
Editorial: Gasking and Geaching
}

Philosophical journals, ex officio, are solemn enough to invite parody and burlesque. We have all heard of, even if few of us have seen, the issue of Mind! edited by F. C. S. Schiller, with a frontispiece consisting of a blank page with the caption 'A Portrait of His Immanence the Absolute'. More recently, when Professor Julius Kovesi and Dr Anthony Kenny were even younger and friskier than they are today, there were several issues of $W h y$ ?, produced without apologies to Analysis, and affording space (e.g.) to 'A Note on Proposing' in which G. Ryle scotched the notion that 'She is charming' is equivalent to 'She is engaged in witchcraft' and offered an alternative analysis in terms of 'winks, ogles and the like'. The philosophy of mind was furthered in another issue by a symposium on the text 'Old King Cole was a merry old soul, and a merry old soul was he.' R. Carnap warned against unwarily supposing that Old King Cole was a merry old pseudo-object rather than a merry old thing-word. The reply by J. Wisdom begins 'Well here's a pretty kettle o' fish and no mistake and not very well punctuated either not that I was ever much of a one for punctuation myself.' (Copies are now rare. These quotations are from memory.)

The latest venture in this fertile field has recently appeared in its 6th Edition. Professor D. C. Dennett has for some years been entertaining himself and us by devising, collecting and circulating entries in a Philosophical Lexicon. Some are more accurate than funny ('kenny'= 'clever'). Others are more funny than accurate: 'To körner' = 'to paraphrase': 'He körnered my ideas with great accuracy but his criticisms were well wide of the mark'. Some hit the double target with both barrels:

chisholm: To make repeated small alterations in a definition or example: 'He kept chisholming away at it.'

flew: An old-fashioned device for blowing smoke into churches.

geach: Indefinable term, which can be learned only by ostension, having to do with the way one reacts to a philosophic issue or individual. 'It made me want to geach.' 'They are sitting in the bar, geaching at Whitehead.' 'It is hard to say whether he is seriously chisholming the definition or just geaching off.'

Professor Dennett is now retiring, but the game will go on. There is already talk of a 7 th Edition. An entry recently designed in Sydney will have to be exported to Melbourne rather than to California:

gasking: Present participle of the verb 'to gask': to wait for something to occur: 'He was gasking in the sun waiting for an argument to occur to him.' 